Journal of Social Sciences 6 (2): 179-185, 2010

ISSN 1549-3652

(C) 2010 Science Publications

\title{
Pension Reform Act 2004: An Overview
}

\author{
F. Olurankinse \\ Department of Accounting, Adekunle Ajasin University, \\ Akungba-Akoko, Ondo State, Nigeria
}

\begin{abstract}
Problem statement: The study critically analyzed the impact of the current pension reform scheme in the public service in Nigeria. Approach: The study revealed the public concern over pension matters and focused on ways to improve quality of life after service and how to increase life expectancy of pensioners in Nigeria. Results: The urgent need of reform necessitated the carrying out of this research, due to the fact that public sector organization at both the federal, state and local government levels have woefully failed to meet their pension liabilities thereby groaning under the heavy burden of paying the retirement benefits of retirees. The scourge of "ghost pensioners, has further aggravated the lingering pension crisis. The analytical tool used, was chi-square in which expected frequency tables were computed. The findings of the study revealed that, a pensioner under former policy of pension scheme (defined benefit scheme) has suffered neglect in receiving their gratuities and pensions. Many pensioners gave off the ghost before they could access reasonable percentage of their pension benefits. Conclusion/Recommendations: The study recommended the use of a uniform pension scheme for both the public and the private sectors and that retirement benefits should be funded by both the employer and the employee. Also, strict regulation of the activities of pension fund Administrators and National pension commission is to be established and charge with the responsibility for the regulation, supervision and effective administration of all pension matters in Nigeria.
\end{abstract}

Key words: Pension act 2004, defined benefits, gratuities, contributory, NAICOM, stake holders

\section{INTRODUCTION}

Pension is simply the amount set aside either by an employer or the employee or both to ensure that at retirement, there is something to fall back on as income (Ahmed, 2006). It ensures that at old age they will not be stranded financially. Pension is a plan for the rainy days after retirement. The maxim one who fails to plan for the rainy day is simply being ready to be swept by the rain when it comes. Many people do not believe in planning for the future because they believe that it is a sin to be anxious about tomorrow because to them it is only God that can care for tomorrow. Due to the fact that Nigeria does not have a robust social security system as it exist in other developed country like America and considering the polygamous nature of the African, one can be correct to say that there is no sin for one to plan for himself to the point when the body will not be fit for him to work.

Pension reform according to Blake (2003) is not a new issue in any part of the world. It is usually a continuous process especially with the ever changing economic and political process witnessed in all the part of the world. The United Kingdom which is one of the first countries to introduce pension scheme has conducted several pension reforms, the latest being the pension reform under the Labor government of Tony Blair in 1997 (David, 2003). Nigeria's first ever legislation instrument on pension matters according to Balogun (2006) was the pension ordinance of 1951, which had retrospective effect from 1st January, 1946. The National Provident Fund (NPF) scheme established in 1961 was the first legislation enacted to address pension No. 102 of 1979, as well as the Armed forces pension Act No. 103 of the same year. The police and other government agencies' pension scheme was enacted under the pension Act No.75 of 1987, followed by the local government pension Edict which culminated into the establishment of the local government staff pension Board of 1987. In 1993 the National Social Insurance Trust Fund (NSITF) scheme was established by Decree No. 73 of 1993 to replace the defunct NPF Scheme with effect from 1st July, 1994 to cater for employees in the private sector of the economy against loss of employment income in old age, invalidity or death. Prior to the Pension Reform Act 2004 (PRA) (National Assembly of the Federal Republic of Nigeria, 2004; Pension Reform Act, 2004), 


\section{J. Social Sci., 6 (2): 179-185, 2010}

most public organization operated a Defined Benefit (pay-as-you-go) scheme. Final Entitlement were based on length of service and terminal emoluments. The Defined Benefit Scheme (DBS) was funded by Federal Government through budgetary allocation and administered by pension Department of the Office of Head of service of the Federation.

Statement of problem: In the last two and a half decades, most pension scheme in the public sector had been under- funded, owing to inadequate budgetary allocations. Budget releases which seldom came on scheme were far short of due benefits. This situation had resulted unprecedented and unsustainable outstanding pension deficits estimated at over N2 trillion before the commencement of the PRA in 2004. The proportion of pension to salaries increases from 16.7-30\% between 1995 and 1999 (Balogun, 2006). The administration of the scheme was generally weak, inefficient and non transparent. There was no authenticated list/data base on pensioners, while about 14 documents were required to file pension claims. Also, restrictive and sharp practices in investment and management of pension fund exacerbated the problem of pension liabilities to the extent that pensioners were dying of verification queues and most of the over 300 parastatals schemes were bankrupt before the new scheme came on board. As regards the private sector, most employees in the formal establishments and all those engaged in the informal enterprises were not covered by any form of retirement benefit arrangements. Most pension scheme was designed as "resignation" scheme rather than "retirements" scheme. Generally, the pension schemes in Nigeria were largely unregulated, without any standard or supervision and highly diversified before the advent of the PRA 2004 (Hassana, 2008). It was against this backdrop, according to Balogun (2006) (op cit) that the federal government constituted various committees (headed by Chief Ajibola Ogunsola and Fola Adeola) at different time to look into the challenges of pension scheme in Nigeria and poffer solution. It was the Fola Adeola committee report (The Committee, 1997) that was enacted into the Pension Reform Act (PRA) and came into operation 1st July, 2004.

Literature review: Pension and related issues had received significant attention in many countries over the recent past decades. There are changes in the way pension assets are managed and benefit 'distributed to beneficiaries due to the difficulty attributed with the pension Schemes existing in this country. Many countries have opted for different form of contributory Pension Scheme, in which employees and their employers are expected to pay certain percentage of the employees' monthly earning to a Retirements Saving Account (RSA) from which they would be drawing their Pension benefits after retirement (Robolino, 2006; World Bank Institute, 2006; Taiwo, 2006). Balogun (2005) said that the legislative document on Pension in Nigeria was the Pension Ordinance of 1951, with retroactive effect from January 1, 1946. The law provided public servants with both pension and gratuity. Pensions Decrees 102 and 103 (for the Military) of 1979 were enacted, with retroactive effect from April 1974. Theses Decrees remained The Operative laws On Public serve and Military Pension in Nigeria until June 2004. However, there are several government circulars and regulations issued to alter their Provisions and implementations. For example in 1992, the qualifying period for gratuity and pension were reduced from 10-5 years and from 15-10 years respectively. On the other hand, the first private sector pension Scheme in Nigeria was set up for the employees of the Nigerian Breweries in 1954; this was followed by United African Company (UAC) in 1957. National Provided Fund (NPF) was the first formal social protection Scheme in Nigeria established in 1961 for the non-Pensionable private sector employees. The Nigeria Social Insurance Trust Fund (NSITF) was established by Decrees No. 73 of 1993 to provide and enhance social protection to private sector employees (Ahmed, 2006).

There were three regulators in the pension industry prior to the enactment of the pension Reform Act 2004; namely Securities and Exchange Commission (SEC), National Insurance Commission (NAICOM) and Join Tax Board (JTB). SEC licensed pension managers while NAICOM is still the agency responsible for licensing and regulating insurance companies in the country. The JTB approved for monitor all private pension schemes with enabling powers from schedule 3 of the personal Income Tax Decrees 104 of 1993 (Dalang, 2006). The pension Reform Act 2004 is the most recent legislation of the federal government reforming the pension system in the country. It established a uniform pension system for both public and private sectors. Similarly, for the first time in history of the country, a single authority has been established to regulate all pension matters in the country. The Nigeria economy according to Chilekezi (2005) consists of both the public and private sectors and both of them have pension plans for their employees which are differently organized. 


\section{J. Social Sci., 6 (2): 179-185, 2010}

\section{MATERIALS AND METHODS}

The public sector scheme: In the government's scheme, the government funded the scheme $100 \%$. This is also called non contributory pension scheme. The government does so through budgetary allocation for the payment of pension in each fiscal year (Chilekezi, 2005). It is important to note that the first pension Act was promulgated in 1951 and it was replaced by the pension Decrees 1979 (or Decree 102) with its provisions backdated to April 1974.The law regulating the pension of the armed forces was the pension Decree203 of 1979 which is similar to that of Decree 102 commenting on the provisions of the Decree 102 of 1979. Uzoma (1993) noted that "in the special case of the public scheme the office of Establishment and pensions acts as the trustee and constitutes the rules of the scheme. Because of the nature of government, Regular circulars are issued by the office of Establishments and pensions to all Ministerial Departments in order to ensure that desk officers understand and interpret the pensions Decree, 1979 in a uniform manner." The scheme was for all public servants except those in that capacities who were on temporary or contract employment. The compulsory retirement age for such worker was 60 years for both male and female workers except for high court Judges that was 65 and 70 years for Justices of court of Appeal and Supreme Court. However, the early retirement was 45 years provided the worker has put in 15 years of service or more. The benefit of this scheme is divided into two, vis-à-vis, a lump sum benefit or gratuity and pensions payment for life. For a person retiring after 10 years of service, he is only entitling to a lump sum/gratuity of $100 \%$ percent of his annual salary. However, workers who put in 15 years and above service were to be paid both gratuity and pensions.

The private sector scheme: The private sector scheme was better organized than that of the public sector. It was mostly a contributory scheme, however there are few cases of non-contributory schemes which was $100 \%$ funded by the employers (Uzoma, 1993). The two commonest schemes were the self-administered schemes and the insured schemes. The selfadministered schemes were administered on behalf of the staff by the Trustees, In line with the trust Deed and Rules. The administrators not only collected the contribution, they invested such contribution through an external or in-house fund manager. In the case of the insured scheme, the administration of the pension is transferred to a life insurance company which collects the premium and invests same and pays the retirees pension on retirement. A commonest form of this scheme is the deposit administration which allows the insurance company involved to invest pension funds whereby contribution were accumulated and invested with the subsequent interest. It is through the use of the insured scheme or the use of pension fund managers that the private sector managed its Schemes effectively before the advent of the reformed pension scheme (Uzoma, 1993).

Failure of the pension scheme in Nigeria: The Nigeria pension scheme was without its own defects. As pointed out by Gbites (2006) and Kunle and Iyefu (2004) Toye (2004) some of these defects are highlighted below: The Pension Fund Administrators (PFA) were largely weak, inefficient and cumbersome and lacked transparency in its activities. Those in the private sector had low compliance ratio. Some of the defects are highlighted below:

- The scheme in the public sector became unsustainable and further compounded by increase in salaries and pension payments

- The outright corruption and embezzlement that existed in the country also affected the pension scheme and fund meant for it

- Poor supervision of pension fund administrators for effective collection, management and disbursement of pension funds

- Poor record and documentation processes of the pension board

- The inability of pension fund administrators to effectively carryout their duty of providing the expected pension as at when due. This development forced workers to become beggars after retirement

The need for pension reform in Nigeria: Due to the deficiencies that existed in the old pension scheme there was need for the reform of the existing pension scheme. The need for reform became inevitable because the longer the reform was delayed the more difficult it became to implement. Such reform, according to Robolino (2005) should take the following approaches:

- Minor adjustments (parametric reform) to the existing pension scheme. The only problem with such minor adjustments is that if implemented, they will not provide a permanent solution to the problem

- Complete overhauls (Structural reform) of the pension scheme. Although majority of the 
countries adopted minor reforms, the Nigerian government decided on a major reform which involves shifting to a Defined contribution system that fully funded as well as reforming the overall pension system. The idea of the reform of the pension system was first moved by the general Abdulsalam Abubakar by setting up the Ajibola Ogunsola committee. The committee was replaced by the Fola Adeola's committee set-up by the chief Olusegun Obasanjo, which finally led to the enactment of the pension reform Act 2004

The new pension scheme: The new pension scheme known as the "PENSION REFORM Act2004" was establishment for employees in both the public and private sectors. The implementation of the Scheme was in two phases. Phase one included the public Sectors (Federal Ministries and its related Agencies) which were to commence from July 2004 and phase two mainly the private sector (with 5 or more employees) to commence from January 2005.

Under the new scheme the employer does not guarantee any certain amount in retirement. The payments that will be made to qualifying participants upon retirement will depend on the scheme which is contributory in nature. The new scheme makes it mandatory for employers and workers in both the public and private sector to each contribute $7.5 \%$ of the emoluments into a Retirement Savings Account (RSA) that is to be opened for each employee. For the military, the contribution is $2.5 \%$ by the employee and $12.5 \%$ by the government.

Implementation of the new pension scheme: The Act on commencement provides that pension Funds shall only be managed by licensed Pension Fund Administrators (PFAs) who are to open a Retirement Savings Accounts (RSA) for all employees with a Personal Identity Number (PIN) attached through which their contributions could be kept. They are to maintain books of account on all transactions and the money collected is to be invested and managed by the PFA. Sec45 ( $F$ and $G$ ) of the Act makes it the responsibility of the PFA to calculate and pay retirement benefits. The Act provides also that the no one can withdraw from the Retirement Saving Accounts except he has attained 50 year of age. Section 2(2) however gave the ground for such withdrawal before that the age by an employee as following:

- If employee is retired on the advice of a suitably qualified physician or a properly constituted medical board certifying that the employee is no longer mentally or physically capable of carrying out the function of his office

- If employee is retired due to his total or permanent disability either of mind or body

- If employee retires before the age of 50 years in accordance with the terms and conditions of his employment shall be entitle to make withdrawals in accordance with section 4of the Act

The pension fund assets are held by the Pension Fund Custodians (PFCs). They carry out most of the function of the PFA and report any activities concerning the pension fund under their custody to the PFA. The provision for the Act (section 51-54) guides the application, requirement, refusal and revocation of the licenses of the PFC respectively. Accrued pension rights of employees who are to join the new scheme shall be recognized for the period they had worked for government before the commencement of the Act. Actuarial valuation of accrued pension right for federal government employees was concluded and retirement benefit bond will be issued, to be redeemed by the CBN and funded by the government. The national pension commission has embarked on enlighten programmes as part of its implementation process of the reform (Mubaraq, 2005).

Supervission of the pension scheme: Section 14 of the pension Reform Act 2004 make provision for the establishment of a National Pension Commission (NPC) whose objective are to regulate, supervise and ensure effective administration of the pension scheme in Nigeria. The commission is to at least once a year authorized an inspection or investigation of Pension Fund Administrator or Custodian (PFA) or (PFC) in order to ensure full compliance with the Act. The commission shall appoint qualified persons to carry out such examination or investigation as the case may be. The report of such investigation shall be sent to the commission for scrutiny and necessary action. The Act make it an offence for any Employer, PFA or PFC who fail to keep proper books of accounts, document or voucher or give detail information required by an inspector.

\section{RESULTS AND DISCUSSION}

Data for this study were collected through the use of structured questionnaires, oral Interviews and previous publication from authoritative textbooks and journals. The questionnaire and oral interviews constituted the primary source of data while the textbooks and journals constituted the secondary source 


\section{J. Social Sci., 6 (2): 179-185, 2010}

of data (Owojori, 2001). A total of thirty (30) workers from public sector (civil servants) and forty-five (45) workers from private sector in Ondo state, were surveyed. Two hundred and twenty-five copies of the (225) questionnaires were distributed and one hundred and eighty (180) were returned producing a response rate of eighty percent (80\%). The objective of the study is to emphasize the importance of pension Reform Scheme in public service. In order to have a proper direction and guide to the study, the following null hypothesis was formulated:

Ho: There is no significant relationship between pension Reform Scheme and Public service

The questionnaire were properly structured to generate "Yes" or "No" answers. This was done to increase rate of response by respondents in the sampled workers.

The figures in parentheses are the Expected frequencies (Err), while those not in parentheses are the observed frequencies (Or).

The Expected frequencies (ER) are computed using the following formula:

$$
\mathrm{Er}=\frac{\text { Correspond in } \mathrm{g} \text { column total } \times \text { corresponding row total }}{\text { grand total }}
$$

For responses relating to "Not significant" the expected frequencies (Er) are:

$\operatorname{Er}=\frac{52 \times 60}{180}=17 \quad($ Under workers from public sector)

$\mathrm{Er}=127 \times 120=85$ (Under workers from private sector)

For responses relating to "significance" the expected frequencies Er are:

$\mathrm{Er}=\frac{127 \times 60=42}{180}($ Under workers from public sector $)$

$\mathrm{Er}=127 \times 120=85($ Under workers from private sector $)$

From the Table 1 and 2, the chi-square statistics $\left(\mathrm{x}^{2}\right)$ is calculated using the ing formula:

$x^{2}=\frac{(\mathrm{Or}-\mathrm{Er})}{\mathrm{Er}}$

Where:

Or $=$ Observed frequencies

$\mathrm{Er}=$ Expected frequencies
Table 1: Pension reform scheme in relation to public service

\begin{tabular}{lllc}
\hline & $\begin{array}{l}\text { Workers from } \\
\text { public sector }\end{array}$ & $\begin{array}{l}\text { Workers from } \\
\text { private sector }\end{array}$ & Total \\
\hline Significant & 52 & 75 & 127 \\
Not significant & 8 & 45 & 53 \\
\hline Total & 60 & 120 & 180 \\
\hline
\end{tabular}

Source: Questionnaire administered

Table 2: Computation of expected frequencies

\begin{tabular}{lllr}
\hline & $\begin{array}{l}\text { Workers from } \\
\text { public sector }\end{array}$ & $\begin{array}{l}\text { Workers from } \\
\text { private sector }\end{array}$ & Total \\
\hline Sig significant & $52(42)$ & $75(85)$ & 127 \\
No significant & $8(17)$ & $45(35)$ & 53 \\
\hline Total & 60 & 120 & 180 \\
\hline
\end{tabular}

Source: Questionnaire administered

Table 3: Chi-square distribution

\begin{tabular}{llrr}
\hline & Area in shaded right tail & \\
Degrees of & - & 0.050 & 0.010 \\
freedom (df) & 0.0100 & 3.841 & 6.635 \\
\hline 1 & 2.7060 & 5.991 & 9.210 \\
2 & 4.0605 & 7.815 & 11.345 \\
3 & 6.2510 & 9.448 & 13.277 \\
4 & 7.7790 & 11.070 & 15.086 \\
5 & 9.2360 & &
\end{tabular}

$$
\begin{aligned}
x^{2} & =\frac{(52-42)^{2}}{28}+\frac{(75-85)^{2}}{85}+\frac{(8-17)^{2}}{17}+\frac{(45-35)^{2}}{35} \\
& =2.381+1.176+4.764+2.857 \\
& =11.178
\end{aligned}
$$

The degree of freedom (df) is calculated as follows:

$$
\mathrm{Df}=(\mathrm{R}-1)(\mathrm{C}-1)
$$

Where:

$\mathrm{R}=$ Number of Rows

$\mathrm{C}=$ Number of Columns

$\mathrm{Df}=(2-1)(\mathrm{C}-1)=1$

At 5\% significant level with one (1) degree of freedom, the critical value of chi-square $\left(\mathrm{x}^{2}\right)$ obtained from the chi-square $\left(\mathrm{x}^{2}\right)$ distribution shown in Table 3 is 3.841 .

Data collected were presented in a contingency table. They were analyzed using simple percentages as well as chi- square $\left(\mathrm{x}^{2}\right)$ test statistic. The chi-square $\left(\mathrm{x}^{2}\right)$ test statistic was applied to the null hypothesis to subject it to statistical decision based on empirical results of the study. The contingency table is disclosed in Table 1 summarizing the result of the survey on significance of pension Reform Scheme in relation to public service. The data contained in Table 1 shows that one hundred and twenty seven (127) were of the 83 
opinion that Pension Reform Scheme is significant when related to public service, while fifty three (53) respondents maintain that it is insignificant when related to public service. "Relatively the result is seventy-one percent $(71 \%)$ in favor of the view that Pension Reform Scheme is significant when related to Pension reform Scheme and twenty-nine percent (29\%) are against the view. The results were also subjected to statistic decision. The chi-square $\left(\mathrm{x}^{2}\right)$ test statistic was applied. Table 2 provides the computation of expected frequencies based on the results of the survey.

The risk of rejecting the null hypothesis otherwise called the significance level was chosen to be five percent $(5 \%)$, thus, producing a confidence level of ninety-five percent (95\%). Based on the number of columns and rows under Table one (1) degree of freedom (df) was established. From Table 2, the chisquare $\left(\mathrm{x}^{2}\right)$ was calculated to be 11.178 . At five percent (5\%) level of significance given one (1) degree of freedom (df) the critical value of chi-square $\left(x^{2}\right)$ is 3.841 (Table 3$)$. The computed value of chi-square $\left(x^{2}\right)$ of 11.178 exceeds the critical value of 3.841 . As a result, the null hypothesis that "there is no significant relationship between Pension Reform Scheme and Public Service was rejected. There fore, the view that there is significant relationship between Pension Reform Scheme and Public Service was realized.

During the findings, it was discovered that some organizations that adopted Defined Benefits Scheme did not implement recommendations contain therein. Those organizations that implemented the recommendations made by the Government did that in a very care free way, thereby making the entire exercise historical. The survey also disclosed that organizations in this category of not implementing recommendations are mainly Public Sectors at all level of governments. A few of the private organizations implemented the policy (Defined Benefits Scheme). Responses based on oral interview conducted that resolving weaknesses contained in Defined Benefits Scheme leads to need for public service to adopt a new Pension Reform Scheme (Contributory Pension Scheme) more reliable and benefiting by the employees and employers.

\section{CONCLUSION}

The Pension Reform Act 2004 is an instrument whose success depends on the sincerity and commitment of all stake holders, all the stakeholders in this context mean the employers, employees, the PFAs and the PFCs, the Transition Arrangement Committees, the NSITF and the PENCOM. One of the most important ways to ensure the success of the scheme is to protect the funds subject of the scheme and make sure they are not frittered away by either fraudulent or incompetent fund administrator or as a result of bad investment decisions. Since one of the major policy considerations behind the enactment of the Act is the desire to provide for the worker in old age or during ill health and to ensure his financial wellbeing. Any mismanagement of the funds will mean a failure of the scheme as target workforce will have little or nothing to cushion the economic hardship that may then arise. In addition, the act must provide for a relatively safe and less volatile area in the Nigerian economy where the funds might be invested within commensurate returns assured to the beneficiaries. To this end, fund administrators should be competent and proven institutions in financial and investment. Pension Reforms are a continuous exercise and always subject to reviews and updates just like the experience of advanced countries like Britain, the case of Nigeria is not different. Therefore, the Pensions Reforms Act2004cannot be final. To ensure that the existing scheme are continued and maintained, the following recommendations are suggested:

- Pension Commission should provide enable environment for smooth implementation of the new pension Act

- Pension Commission should ensure effective monitoring of all players, adequate sanction of erring operators and good coverage of all stakeholders

- Relevant legal framework should be put in place by the federal government to ensure political economic and necessary supports for the scheme by subsequent governments.

- The new scheme should be rigorously audited and monitored for any non Compliance

- There is need for uniform pension for both public and private sectors and the scheme must be funded by both the key players

\section{REFERENCES}

Ahmed, M.K., 2006. The Contributory pension scheme: Institution and legal framework. CBN Bull., 3: 1-6. Balogun, A., 2006. Understanding the new pension reform act 2004. CBN Bull., 3: 7-18.

Blake, D., 2003. The United Kingdom Pension Scheme in Nigeria. Pension Institute, Bareback College, University of London, pp: 67-79.

Chilekezi, O.C., 2005. Outline of Reformed Pensions Scheme in Nigeria. Lagos, ISBN: 9783827871, pp: 71. 
Dalang, L.D., 2006. Investment and Risk Management under the New Pension Scheme. Sigma vaughu Sterling Pension Scheme, Abuja.

David, B., 2003. United Kingdom pension system: Key issues. Technical Report, Text Version. http://hermes-ir.lib.hitu.ac.jp/rs/bitstream/10086/14379/1/pie_dp15.pdf

Gbites, B., 2006. Understanding Pension Fund Investment Guideline. This Day Newspapers, IBTC wealth Management Series, Nigeria.

Hassana, A.K., 2008. Pension fund hits 4.4 bn. Daily Trust, Abuja.

Kunle, A. and A. Iyefu, 2004. Why pension scheme fail in Nigeria. This Day Online, Abuja. http://www.globalaging.org/pension/world/2004/ni geria.htm

Mubaraq, S., 2005. Business statistics for social scientists. Proceeding of the National Pension Commission Seminar on the Pension Reform, Aug. 2006, Olad Publishers and Printed Enterprises, Ilorin, Kwara, pp: 40-57.

National Assembly of the Federal Republic of Nigeria, 2004. The pension reform act 2004. Vanguard, Lagos, pp: 1-39. http://www.pencom.gov.ng/index.php?option=com _content $\&$ view $=$ article $\&$ id $=59$
Owojori, B., 2001. Research Methodology. Kaycer Publishers, Ado-Ekiti, pp: 71-92.

Pension Reform Act, 2004. Federal republic of Nigeria official gazette. No. 60, Vol. 91 Government Notice Number 133, pp: 29-67.

Taiwo, O., 2006. Pension reform matter arising.

The Committee, 1997. Report of the vision 2010 committee.

http://openlibrary.org/b/OL3551031M/Report_of_t he_Vision_2010_Committee

Toye, O., 2004. Pension Plans Fails and Elderly Becomes Beggars. Lagos, Inter press Services, Nigeria, pp: 3-19.

Uzoma, P., 1993. Pension scheme in Nigeria. Gentle Press Ltd and Kubay Associates Ltd., Ikeja, Lagos, pp: 231-276.

World Bank Institute, 2006. World Bank core course, on pensions. The World Bank Institute, Washington DC.

http://siteresources.worldbank.org/SPLP/Resources /461653-

1151082099426/CoreCourseAgenda2006.pdf 